\title{
Application of FT NIR Spectroscopy in the Determination of Basic Physical and Chemical Properties of Sausages
}

\author{
Zuzana Procházková1, Michaela Dračková ${ }^{1}$, Alena Saláková2, Leo Gallas², \\ Matěj Pospiech ${ }^{3}$, Lenka Vorlová ${ }^{1}$, Bohuslava Tremlová ${ }^{3}$, Hana Buchtová ${ }^{2}$ \\ ${ }^{1}$ Department of Milk Hygiene and Technology, ${ }^{2}$ Department of Meat Hygiene and Technology, ${ }^{3}$ Department \\ of Vegetable Foodstuffs and Plant Production, Faculty of Veterinary Hygiene and Ecology, \\ University of Veterinary and Pharmaceutical Sciences Brno, Czech Republic
}

\author{
Received October 20, 2009 \\ Accepted April 6, 2010
}

\begin{abstract}
The objectives of this study were to develop calibration models for determination of water activity and the content of fat, dry matter, salt, non collagen muscle protein and $\mathrm{pH}$ in dry cooked sausages. Samples $(n=42)$ were scanned in FT-NIR Analyzer and simultaneously analyzed by standard methods. The spectra were measured in the reflectance mode with a compressive cell between 10000 and $4000 \mathrm{~cm}^{-1}$, averaging 100 scans. Calibration models were developed using the partial least squares (PLS) method. These calibration models were checked later by crossvalidation. The following statistical values were obtained: $\mathrm{R}$ (correlation coefficient) $=0.997$ and $\mathrm{SEC}$ ( standard error of calibration) $=0.002$ for water activity, $\mathrm{R}=0.966$ and $\mathrm{SEC}=0.023$ for $\mathrm{pH}$, $\mathrm{R}=0.995$ and $\mathrm{SEC}=0.970$ for dry matter content, $\mathrm{R}=0.995$ and $\mathrm{SEC}=0.045$ for salt content, $\mathrm{R}=0.965$ and $\mathrm{SEC}=0.652$ for non collagen muscle protein, $\mathrm{R}=0.996$ and $\mathrm{SEC}=0.559$ for fat content. The results of the study showed that FT-NIR is a suitable method for rapid analysis of physical and chemical properties of sausages.
\end{abstract}

FT-NIR, spectroscopy, calibration models, sausages

Fourier Transform Near Infrared (FT-NIR) spectroscopy has been a success in the chemical analysis industry thanks to a number of advantages, as it is a rapid and exact method. In the dairy industry, spectroscopy in the infrared region is used for assessing lactose, protein and fat contents in milk. It is also used in the cereals and feedstuffs producing industries. It has been shown in the course of the last three decades that NIR is also a very efficient and promising method for the assessment of meat and meat product quality (Prieto et al. 2006; Ripoll et al. 2008).

Advanced countries face a high demand for meat and meat products that are appreciated by consumers as valuable nutritional components. In order to keep the standard quality of meat products required by the consumers, it is necessary to carry out a series of quality checks. Various assays are commonly used to assess meat and meat product quality when evaluating their physical, chemical, microbiological and sensory properties. The traditional methods are, however, very time-consuming and, as a result, unusable in the production line analysis ( $\mathrm{Liu}$ et al. 2004). In comparison with conventional methods for assessing meat indicators, near infrared spectroscopy is a sensitive, rapid and non-destructive analytical technique with a simple sample preparation and it allows for simultaneous assessment of several variables (Prieto et al. 2006). NIR spectroscopy is successfully applied when assessing the quantities of the main components (water, fats and proteins) in meat and meat products (Prevolník et al. 2004; Berzhaghi et al. 2005; Gaitan-Jurado et al. 2008; Prieto et al. 2006; Viljoen et al. 2007).

The goal of this project was to create calibration models for assessing the important physical and chemical properties of quality in dry cooked sausage "Vysočina", namely in the following areas: water activity, $\mathrm{pH}$, dry matter content, salt content, non collagen muscle protein content and fat content.

Address for correspondence:

MVDr. Zuzana Procházková

Department of Milk Hygiene and Technology

Faculty of Veterinary Hygiene and Ecology

University of Veterinary and Pharmaceutical Sciences Brno

Palackého 1/3, 61242 Brno, Czech Republic

Phone: +420541562722
Fax: +420 541562711
E-mail: zprochazkova@vfu.cz
http://www.vfu.cz/acta-vet/actavet.htm 


\section{Materials and Methods}

In this study, 42 samples of the Vysočina sausage were examined at the technological workshop of the Department of Meat Hygiene and Technology of the University of Veterinary and Pharmaceutical Sciences Brno. The Vysočina sausage belongs to the group of dry cooked sausages. It is made of beef and pork backfat. Before analysis, the sausage was stored according to applicable regulations. The sample parameters (water activity, $\mathrm{pH}$, dry matter content, salt content, non collagen muscle protein content and fat content) were assessed using both standard methods and FT-NIR spectroscopy. The sausage samples $(100 \mathrm{~g})$ were homogenized. The following properties were subsequently determined: amount of dry matter (International Standard, 1997) and fat analysed on the Soxtec (FOSS Tecator AB, Sweden) with diethylether as the extraction agent (Application Sub Note 2001). The protein content was determined as an amount of organically bound nitrogen (recalculating coefficient $\mathrm{f} 1=6.25$ ) after precipitation with hot tannine solution using the Kjeltec 2300 (FOSS Analytical AB, Sweden) semiautomatic analyzer following the method recommended by the producer (Application Note 2003). The content of collagen was computed from the content of hydroxyproline amino. The content of collagen in samples was determined after $14 \mathrm{~h}$ hydrolysis of $1 \mathrm{~g}$ of sausages with $25 \mathrm{ml} \mathrm{H} \mathrm{SO}_{4}\left(300 \mathrm{~g} \cdot \mathrm{l}^{-1}\right)$ at $105^{\circ} \mathrm{C}$. Hydrolysates were neutralized with $\mathrm{NaOH}\left(10 \mathrm{~mol} \cdot \mathrm{l}^{-1}\right)$, and diluted with distilled water to $100 \mathrm{ml}$ and filtrated. Then $1 \mathrm{ml}$ of filtrated hydrolysates together with $1 \mathrm{ml} 0.01 \mathrm{~mol}^{-1} \mathrm{C}^{-1} \mathrm{CuSO}_{4}, 1 \mathrm{ml} 2.5 \mathrm{~mol} \cdot \mathrm{l}^{-1} \mathrm{NaOH}$ and $1 \mathrm{ml} 6 \% \mathrm{H}_{2} \mathrm{O}_{2}$ were mixed in a test tube. The solution was shaken and heated at $80^{\circ} \mathrm{C}$ until it turned blue. Then $4 \mathrm{ml} 3 \mathrm{~mol}^{2} \cdot 1^{-1} \mathrm{H}_{2} \mathrm{SO}_{4}$ and $2 \mathrm{ml}$ p-dimethylaminobenzaldehyde were added. The solution was shaken and heated at $70^{\circ} \mathrm{C}$ for $16 \mathrm{~min}$. The samples were consequently cooled in tap water and the absorbance measured at $550 \mathrm{~nm}$ on UV/VIS spectrophotometer (Neo $1000, \mathrm{UK})$. The amount of hydroxyproline was determined from a standard curve. The collagen content was calculated from hydroxyproline content using the coefficient 8 .

Sausage samples for FT- NIR spectroscopy testing were homogenized by blending in a blender. Every sample was measured three times; average spectrum was used for calibration. Samples were measured in the NIR Nicolet Antaris (Thermo Electron Corporation, Madison, USA) spectrometer in the spectrum range of $10000-4000 \mathrm{~cm}^{-1}$ using 100 scans with the spectral resolution 8 . One spectrum recording bordered on $90 \mathrm{~s}$. The spectra were measured on an integration sphere in the reflectance mode with a compressive cell. The acquired data were processed using the TQ Analyst version 6.2.1.509 software employing the partial least square (PLS) method, which was verified using the cross validation on the same set of samples that were used for calibration. During the process, one of the standards was always skipped and a new model was created from the remaining calibration data, which was consequently used for the calculation of the concentration vectors of the skipped standards. The calculated deviations from the component contents of the skipped standards were then assessed statistically (Mlček et al. 2006). To identify the outlying spectra and standards, the Spectrum Outlier and Leverage diagnostic methods were utilised. Also, an optimum number of PLS factors for calibration was selected (PRESS) (Fig. 1).

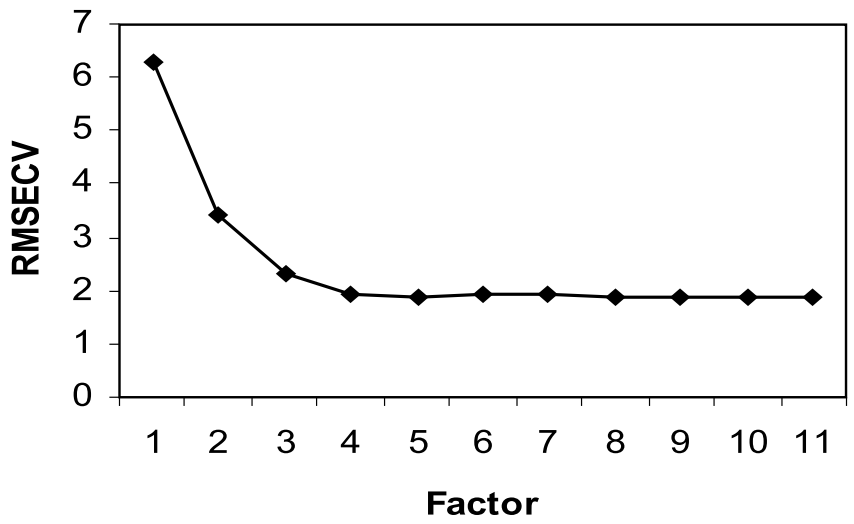

RMSECV - root mean square error of cross validation

Fig. 1 PRESS for fat content

Basic statistical characteristics (mean, standard deviation, minimum, maximum) for all the reference parameters were calculated using Microsoft Excel 2003. Statistical assessment of the data was carried out using the statistical and graphic software STAT Plus (Matoušková et al. 1992). Paired $t$-test was used to compare the values acquired by FT-NIR with the values acquired by reference methods. No significant differences between the values acquired by the reference methods and values calculated using FT-NIR were found. 


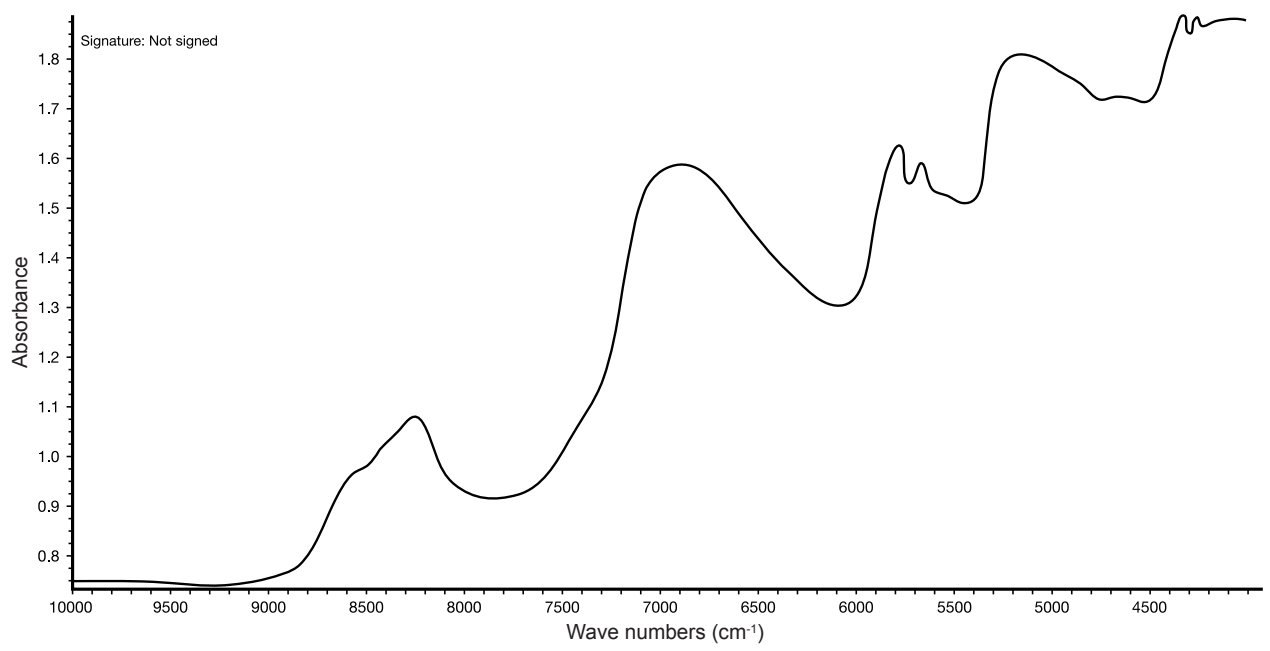

Fig. 2 Spectrum of sausage

\section{Results and Discussion}

Sample spectra were measured in the frequency range of $10000-4000 \mathrm{~cm}^{-1}$. A sausage spectrum example is presented in Fig. 2. The ranges of reference values for the given parameters were expressed by means and standard deviations of the mean (Table 1). No significant results $(p<0.05)$ were found between the reference and calculated values when using FT-NIR.

Table 1. Values of the individual parameters, established by reference methods $(n=42)$

\begin{tabular}{|l|c|c|c|c|}
\hline $\begin{array}{l}\text { Calibrated } \\
\text { parameters }\end{array}$ & Mean & $\begin{array}{c}\text { Minimum } \\
\text { value }\end{array}$ & $\begin{array}{c}\text { Maximum } \\
\text { value }\end{array}$ & $\begin{array}{c}\text { Standard } \\
\text { deviation }\end{array}$ \\
\hline Water activity & 0.937 & 0.900 & 0.970 & 0.027 \\
\hline pH & 6.02 & 5.83 & 6.18 & 0.07 \\
\hline Dry matter (\%) & 60.10 & 47.69 & 71.73 & 9.79 \\
\hline Salt (\%) & 2.94 & 2.31 & 3.58 & 0.45 \\
\hline NCMP (\%) & 14.55 & 10.58 & 18.27 & 2.50 \\
\hline Fat (\%) & 36.25 & 26.36 & 45.19 & 6.25 \\
\hline
\end{tabular}

NCMP - non-collagen muscle protein
With the help of diagnostic devices called Spectrum Outlier and Leverage, outlying standards were removed, in which reference values were established incorrectly or there was a spectrum deviation. In case of the $\mathrm{pH}$ parameter one spectrum was removed and in case of the fat content parameter 4 spectra were removed, however, in other parameters no spectra were removed. In the $\mathrm{pH}$, a lower standard error of cross validation (SECV) was obtained after the modification of the calibration model with the first derivative. To achieve the best calibration model, second derivative was used for the fat content. Alomar et al. (2003) also acquired the best calibration model for fat in beef with the use of the second derivative. Oh (1995) compared the use of the first and second derivative for the creation of the calibration models for meat patties. He acquired lower SEP (standard error of prediction) in water activity, fat and protein contents using the first derivative than in case of the second one. For muscle protein content, the results he acquired were better in both the first and the second derivatives, as opposed to our model, which was created without deriving. Ripoll et al. (2008) present in their paper that the first derivative is better to be used for samples with homogenous structure as the second derivative displays better results in heterogeneous products. For measuring physical and chemical indicators and 
sensory properties of beef, he used the first derivative for the monitored values. Compared to muscle tissue, sausage is far from being, however well blended, a homogeneous mix. Despite the fact, we used the first derivative in the $\mathrm{pH}$; in the other parameters, the second derivative or no derivative at all was used. Our results do not confirm the theory of the suitability of various types of derivatives regarding the degree of the sample homogeneity. The same results were also reported by other authors (Gaitan-Jurado et al. 2008).

The calibration models for all the monitored parameters were created using the PLS algorithm. PLS was used in the monitored samples of the spectral as well as concentration information to assess the latent variable PLS factors in a data set (Sørensen and Jepsen 1998). In PLS, the new variables are those PLS factors, which are linear combinations of original algorithms. They are calculated in such a way so that the covariance between the PLS factors and analyte concentrations is maximized (Blanco et al. 1997). The highest number of factors was recorded for the salt parameter (10 factors), the least number of factors was recorded in water activity ( 2 factors), for muscle protein and fat contents, 4 factors were used (Table 2). Mlček et al. (2006) detected 5 and 6 PLS factors in these samples, in water contents, there were 3 factors.

Table 2. Calibration and validation results of the individual parameters, established by FT-NIR spectroscopy $(\mathrm{n}=42)$

\begin{tabular}{|l|c|c|c|c|c|c|c|}
\hline \multirow{2}{*}{$\begin{array}{l}\text { Calibrated } \\
\text { parameters }\end{array}$} & \multirow{2}{*}{ PLS factors } & \multicolumn{3}{|c|}{ Calibration } & \multicolumn{3}{c|}{ Validation } \\
\cline { 3 - 8 } & & $\mathrm{R}$ & $\mathrm{SEC}$ & $\mathrm{CCV}(\%)$ & $\mathrm{R}$ & SECV & PCV $(\%)$ \\
\hline Water activity & 2 & 0.997 & 0.002 & 0.25 & 0.975 & 0.007 & 0.72 \\
\hline $\mathrm{pH}$ & 4 & 0.966 & 0.023 & 0.38 & 0.905 & 0.377 & 0.63 \\
\hline Dry matter (\%) & 7 & 0.995 & 0.970 & 1.61 & 0.990 & 1.350 & 2.25 \\
\hline Salt (\%) & 10 & 0.995 & 0.045 & 1.53 & 0.983 & 0.080 & 2.75 \\
\hline NCMP (\%) & 4 & 0.965 & 0.652 & 4.48 & 0.953 & 0.749 & 5.15 \\
\hline Fat (\%) & 4 & 0.996 & 0.559 & 1.72 & 0.954 & 1.850 & 5.68 \\
\hline
\end{tabular}

$\mathrm{R}$ - correlation coefficient, SEC - standard error of calibration, SECV - standard error of cross validation, CCV - calibration coefficient of variation, PCV - prediction coefficient of variation, NCMP - non-collagen muscle protein

The calibration model reliability was cross-validated. For creating validation models, the same set of samples was used as in the calibration. Cross validation represents a strong link between the reference and predicted values. The validation accuracy was assessed based on correlation coefficients of validation (R) and standard error of cross validation (SECV) (Sørensen and Jepsen 1998). Based on the assessment of the parameters of calibration coefficients of variance $(\mathrm{CCV})$ and prediction coefficients of variance (PCV), the calibration models reliability was assessed (Albanell et al. 1999) (Table 2). The best results were acquired for water activity, where $\mathrm{R}=0.997$ and $\mathrm{SEC}=0.002$, and for salt content with $\mathrm{R}=0.995$ and $\mathrm{SEC}=0.045$ (Fig. 3). Good results were also acquired using the calibration model for fat content $(\mathrm{R}=0.996, \mathrm{SEC}=0.559)$. Mlč ek et al. (2006) created calibration models for fat, protein and water contents in pork and beef. The following values were obtained: $\mathrm{R}=0.976$ and $\mathrm{SEC}=7.13$ in protein content, $\mathrm{R}=0.998, \mathrm{SEC}=8.17$ in fat content, and in water content: $\mathrm{R}=0.994$ and $\mathrm{SEC}=11.3$.

The assessment of the calibration coefficient of variation (CCV) and prediction coefficient of variation (PCV), with CCV not exceeding the value of $5 \%$ in any of the monitored indicators and in case of PCV the value of $10 \%$, calibration and validation can be seen as highly reliable (Table 2). In order to gain better calibration results in solids and muscle protein content, it would be necessary to modify the values so that they cover the concentration range of the whole sample set more evenly. Reliable calibration models were created for all the monitored parameters. Based on the acquired results, it can be stated that 


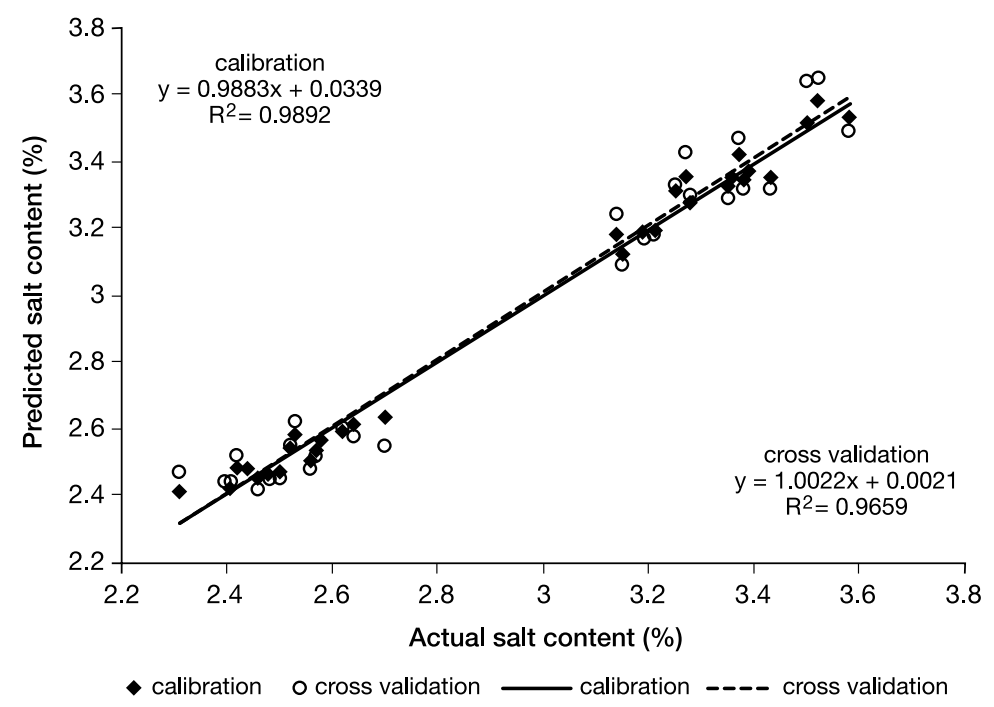

Fig. 3. Calibration and validation model for salt content

FT-NIR spectroscopy is a rapid and suitable method for analyzing physical and chemical properties of sausages.

\section{Užití FT-NIR spektrometrie pro stanovení základních fyzikálně chemických vlastností salámů}

Cílem práce bylo vyvinout kalibrační modely pro stanovení vodní aktivity, obsahu tuku, obsahu sušiny, obsahu soli, obsahu čistých svalových bílkovin a $\mathrm{pH}$ v salámech. Vzorky $(\mathrm{n}=42)$ byly měřeny na FT-NIR spektrometru a současně byla prováděna analýza standardními metodami. Spektra byla naměřena $\mathrm{v}$ režimu reflektance $\mathrm{s}$ použitím kompresní kyvety ve spektrálním rozsahu $10000-4000 \mathrm{~cm}^{-1}$ se 100 scany. Kalibrační modely byly vyvinuty pomocí metody částečných nejmenších čtverců (PLS). Byly získány následující statistické hodnoty: R (korelační koeficient $)=0,997$ a SEC (směrodatná odchylka kalibrace) $=0,002$ pro vodní aktivitu, $\mathrm{R}=$ 0,966 a $\mathrm{SEC}=0,023$ pro $\mathrm{pH}, \mathrm{R}=0,995$ a $\mathrm{SEC}=0,970$ pro obsah sušiny, $\mathrm{u}$ obsahu soli byly hodnoty $\mathrm{R}=0,995$ a $\mathrm{SEC}=0,045$, pro čisté svalové bílkoviny zjištěno $\mathrm{R}=0,965$ a $\mathrm{SEC}=0,652$ a pro obsah tuku pak $\mathrm{R}=0,996$ a $\mathrm{SEC}=0,559$. Výsledky studie ukazují, že FT-NIR je vhodnou metodou pro analýzu fyzikálně chemických ukazatelů salámů.

\section{Acknowledgement}

The project received support from the research plan MSM6215712402 "The Veterinary Aspects of Food Safety and Quality."

\section{References}

Albanell E, Cáceres P, Caja G, Molina E, Gargouri I 1999: Determination of fat, protein and total solids in ovine milk by near-infrared spectroscopy. J AOAC Int 82: 753-758

Alomar D, Gallo C, Castañeda M, Fuchslocher R 2003: Chemical and discriminant analysis of bovine meat by near infrared reflectance spectroscopy (NIRS). Meat Sci 63: 441-450

Application Note 300 2003: The determination of nitrogen according to Kjehldahl using block digestion and steam distillation. Foss Analytical AB Sweden, pp. 1-12

Application Sub Note 3127 2001: Extraction of fat in meat and meat products. Foss Tecator AB Sweden, 1 p.

Berzhaghi P, Dalla Zotte A, Jansson LM, Andrighetto I 2005: Near-infrared reflectance spectroscopy as a method 
to predict chemical composition of breast meat and discriminate between different $n-3$ feeding sources. Poultry Sci 84: 128-136

Blanco M, Coello J, Iturriaga H, Maspoch S, de la Pezuela C 1997: Calibration in near infrared diffuse reflectance spectroscopy. A comparative study of various methods. J Near Infrared Spec 5: 67-75

Gaitan-Jurado AJ, Ortiz-Somovilla V, Espana-Espana F, Perez-Aparicio J, De Pedro-Sanz EJ 2008: Quantitative analysis of pork dry-cured sausages to quality control by NIR spectroscopy. Meat Sci 78: 391-399

International Standard 1442 1997: Meat and meat products: Determination of moisture content (Reference method). Czech office for standards, metrology and testing, pp. 1-4

Liu Y, Lyon BG, Windham WR, Lyon CE, Savage EM 2004: Prediction of physical, color, and sensory characteristics of broiler breasts by visible/near infrared reflectance spectroscopy. Poultry Sci 83: 1467-1474

Matoušková J, Chalupa J, Cígler M, Hruška K 1992: STAT Plus - Manual, version 1.01. (in Czech). Veterinary Research Institute, Brno, 168 p.

Mlček J, Šustová K, Simeonovová J 2006: Application of FT NIR spectroscopy in the determination of basic chemical composition of pork and beef. Czech J Anim Sci 51: 361-368

Oh EK 1995: Measurement of the components in meat patties by near infrared reflectance spectroscopy. Meat Sci 41: 157-162

Prevolnik M, Čandek-Potokar M, Škorjanc D 2004: Ability of NIR spectroscopy to predict meat chemical composition and quality: a review. Czech J Anim Sci 49: 500-510

Prieto N, Andrés S, Giráldez FJ, Mantecón AR, Lavín P 2006: Potential use of near infrared reflectance spectroscopy (NIRS) for the estimation of chemical composition of oxen meat samples. Meat Sci 74: 487-496

Ripoll G, Albertí P, Panea B, Olleta JL, Sañudo C 2008: Near-infrared reflectance spectroscopy for predicting chemical. Instrumental and sensory quality of beef. Meat Sci 80: 697-702

Sørensen LK, Jepsen R 1998: Assessment of sensory properties of cheese by near-infrared spectroscopy. Int Dairy J 8: 863-871

Viljoen M, Hoffman LC, Brand TS 2007: Prediction of the chemical composition of mutton with near infrared reflectance spectroscopy. Small Ruminant Res 69: 88-94 